\title{
Citizen Engagement in the Contemporary Era of Fake News: Hegemonic Distraction or Control of the Social Media Context?
}

\section{Paul R. Carr ${ }^{1}$ (10) Sandra Liliana Cuervo Sanchez ${ }^{2} \cdot$ Michelli Aparecida Daros $^{3}$}

\begin{abstract}
Social media platforms have gained prominence worldwide over the past decade. Texts, images, recordings/podcasts, videos and innovations of all sorts have been created, and can be shared and disseminated, including fake news in all of its dimensions. By playing supposedly a neutral political role, social media platforms are accessible to users, generally without discrimination, in addition to being a lure and target for certain/targeted constituencies. Political parties and politicians have proved that they can shape, influence and win elections through social media and strategies such as 'Twiplomacy'. Social media has the potential to be a democratizing force, yet corporate, neoliberal and hegemonic forces have a tethered grip that can control large swaths of what is happening. This article presents a case study of Spain in relation to fake news, disinformation and misinformation concerning immigration, underscoring that fake news in Spain, like elsewhere, has a long-standing foundation. We explore citizen engagement in the era of social media, referencing as well fake news in Europe and the USA, and make connections with the potential for media literacy as a means to more effectively navigate the murky waters of vast, interwoven online/offline, formal/informal, mainstream/alternative experiences, identities and realities. Lastly, we discuss the implications and consequences for media literacy and democracy, which, we believe, needs to be a central feature of the debate.
\end{abstract}

Keywords Fake news · Misinformation · Hegemony - Democracy $\cdot$ Critical engagement . Education $\cdot$ Media literacy $\cdot$ Spain

Paul R. Carr

prcarr@gmail.com

Sandra Liliana Cuervo Sanchez

sandracuervo.mugak@gmail.com

Michelli Aparecida Daros

michellidaros@gmail.com

Extended author information available on the last page of the article 


\section{Introduction: Conceptual Framework around Information Hegemony ${ }^{1}$}

Within the political realm, disinformation and misinformation are used as tools to maintain power or to generate favorable opinion from citizens in relation to controversial, and often highly objectionable, measures (Carr et al. in press). This 'news' is based on rumors, prejudices, stereotypes and fear as an instrument of persuasion, deception and manipulation. In other words, great efforts are made to affect and influence the emotional side of how people are affected by communications in order to shape and alter citizen behaviour (Van Aelst et al. 2017; Vosoughi et al. 2018). These behaviors occur both in the political and social spheres.

Propaganda meshes with this tapestry of factors framing the reception, consumption, internalization and operationalization of citizen participation, engagement, agency and influence (Braun and Henderson 2016; Carr et al. 2018). Moreover, for Jensen (2016), propaganda can mean very different things at different times in different places; however, there are some guidelines and indicators that can help us to distinguish the types of propaganda and the relation to democracy. To Jensen (2016), democratic persuasion ('healthy propaganda') involves an effort to create background conditions enabling people access to the resources needed to more fully participate in discussion. In this case, discussion is not based on power or money but, rather, in presenting and responding to arguments of others. On the other hand, there is 'undemocratic propaganda' that involves deliberate stories/narratives to support one's interests and/or to ignore, bury, omit or diverge from facts that are in conflict with one's interests.

While the hegemonic control of information was once firmly within the grasp of the mainstream media in coexistence with the State, power elites and business groups, the burgeoning development of the Internet and, significantly, social networks and media has considerably complicated, confused and obfuscated the context. That debate around fake news questions not only the professionalism and legitimacy of journalism and traditional media as well as the veracity of the information - which is firmly entrenched within Democracy and Media 1.0 - but also who has the monopoly or control of information. The potential democratization of media communications, engagement, participation, creation and influence is interwoven into Democracy and Media 2.0, which carries with it a plethora of concerns, caveats, deceptions, digital finger-prints, surveillance issues, algorithms and manipulations. The endlessly diverse internet-based context has re-positioned the debate around what news is available, how it is understood, and how it shapes and constructs realities (Carr et al. in press).

The phenomenon of misinformation is the result of the articulation of and interplay between media, economic interests and political hegemony. A network of actors that seek to direct the opinions/beliefs/perceptions of citizens, especially in relation to representative, electoral politics through voting, has become a focal-point of late, even if we consider it to be only, proverbially, the tip of the iceberg (Carr et al. in press). All of this leads us to question the public function of the media, which is now more radically diffuse, de-centered and potentially much more democratically accessible. Public television, for example, is not truly public in relation to the diversity of opinion but does, to a certain degree, receive public funding aimed at doing so (Casas-Mas 2014; Cuervo Sanchez and Medrano Samaniego 2013).

\footnotetext{
${ }^{1}$ The authors have freely translated into English certain Spanish-language citations.
} 
Within this context, democracy and political participation need to be problematized since understanding, interpreting and engaging with media, communications, information and news is of great concern for education, political and media literacy as well as bone fide citizen engagement (Carr and Thésée 2019). Being aware, sensitized and attuned to what is reality, to whom, how and within what dimensions and contexts, juxtaposed to what is meant to manipulate, contort and unduly influence, owing to ecosystems aimed at falsification and propaganda, is a fundamental concern for us. Everyone is somehow connected to social media today, bringing together online and offline realities, extending and shaping debate, interweaving Democracy and Media 1.0 with Democracy and Media 2.0, with all of the monitoring, tracking, connecting, networking and potential for making a message/theme/issue viral. Some issues are amplified, others diminished or omitted, and everything now plays out somehow through social media, which raises critical concerns about how people/citizens learn about media, information and literacy. The field of critical media literacy is, therefore, a necessary dimension to the equation of fake news (Fleming 2014; Kleemans and Eggink 2016).

In this sense, Maraña (2018) articulates the democratic decline when society is unable to decipher information manipulation and freedom. Within this context, Núñez (2018) states that:

Technology has led to the abundance of information and facilitated access to it, leading to the random, non-linear consumption of information and the selection of sources, direct or indirect sources, ownership of people, personal information. We create our own informative ecosystem, a very personal world, parallel to other personal worlds and the proper ground of post-truth. An ecosystem formed by self-referential information that preserves, in the best of cases, currently, that is not required, any kind of coherence with the previous texts, much less with reality, also causing the perception of all those who do not we have our information ecosystem, they make it deeply biased (Núñez 2018:212)

This article seeks to tie together the overlapping usage, consumption, production, interpretation and influence of social media, which involves online and offline representations, realities, information and networking, with fake news, enveloped within the context of democracy and citizen participation. To do so, we provide a case study of the Spanish context, and how fake news has been operationalized to distort and shape electoral, political and cultural movements as well as meaningful shifts in relation to immigration policy, debate, experience and reality. We are highly cognizant that fake news does not originate (uniquely or specifically) from/in Spain, nor is it uniquely centered within the Spanish reality, and that it is wide-spread, nefarious, fluid, and dependent on how people connect with it (or become indifferent to it). We tease out the Spanish case by briefly delving into fake news in Europe and the USA in relation to immigration, in particular. We are concerned here as well with hegemony and the potential for critical media literacy in order to develop a meaningful democracy with vibrant, critically-engaged citizen participation and engagement. 


\section{Fake News, Misinformation and Propaganda to Distort and Maintain Political Power: The Spanish Case}

Spain is a country in southern Europe, maintaining borders with France to the north and east, and Portugal to the west as well as Morocco to the south. According to the 2014 census, the population is just under 48 million inhabitants. Spain is one of the 28 member states of the European Union. It is divided into 17 regions, called Autonomous Communities, three of which have a co-official language with Spanish (Cataluña, Galicia and País Vasco) as well as a broad historical process undergirding a claim for independence.

At the political and historical level in the 20th and 21st centuries, the period of the Second Republic of 1931-1939 stands out, where progressive changes and reforms affecting the country's social, political and cultural life were introduced. The Spanish Civil War between 1936 and 1939 ended with the establishment of the Franco regime from 1939 to 1975. After the death of Francisco Franco, head of the fascist regime, a transition period was established that culminated with the 1978 constitution. A constitutional monarchy was established as a system of government, and has been in effect ever since. Since the first 'democratic' elections, there has been a bipartisan transferring of power between a center-right party (Unión de Centro Democrático and the Partido Popular) and a center-left party (Partido Socialista Obrero Español) (Casanova and Andres 2009). Currently, the most representative national parties in the Congress are the Partido Popular (PP), the Partido Socialista Obrero Español (PSOE), Unidos Podemos (a confluence of Podemos and Izquierda Unida as well as other leftist parties), Ciudadanos (Cs), Esquerra Republicana de Cataluña (ERC) and Partido Nacionalista Vasco (EAJ-PNV).

In Spain, as is the case in other countries, fake news has played a role throughout its history. We can go back to the Spanish Civil War (1936-1939), with the bombing of Guernica in 1937, which was attributed by the Franco regime to the Republicans, when it was carried out by the German and Italian allies of the dictator Francisco Franco (Beevor 2012). This official version or interpretation was maintained by the Spanish government until the end of the dictatorship in 1975, despite the publication in The Times newspaper on April 26, 1937, by British war correspondent George Steer, who reported that indeed Germany and Italy were responsible for the bombing in Guernica (Pobes and de Maturana Diéguez 2018). This one example could be replicated in almost every military conflict, and vastly predates the Internet. Similarly, the USA involvement in creating and disseminating such propaganda is notorious, and has sown the seeds for untold problems, crises and conflict (Carr et al. 2018).

Another recent and highly nefarious example of a disinformation campaign promoted by the United States relates to the alleged, and never proven, possession and development of weapons of mass destruction by the Iraqi government, which culminated in the incredibly bloody, explosive 2003 Iraq war, and, importantly, resulting in the region being transformed into burgeoning conflict in several areas (Martín Rojo 2007). The vast web of collusion and conspiracy that characterizes this propaganda trap, in the case of the Iraq invasion, involved many other high-level actors, including the Spanish government. For instance, then Spanish President José María Aznar participated in a March 16, 2003, meeting in the Azores with former US President George W. Bush, former Great Britain Prime Minister Tony Blair and former Portugal 
Prime Minister José Manuel Durão Barroso, from which came the ultimatum to Iraqi President Saddam Hussein to relinquish the non-existent weapons of mass destruction, prior to the March 20 invasion of Iraq (Haidar 2018; Ibisate 2018). The role of the international mainstream media, in lock-step with the official hegemonic authorities, should be a concern to anyone interested in critical participation in a robust, criticallyengaged democracy (Carr and Thésée 2019).

This ultimatum to Saddam Hussein is intertwined with the terrorist attacks on four short-distance trains, on March 11, 2004, in Madrid by a Jihadist cell, and, subsequently, involved the political use of the information by the Popular Party government. The ten explosions that occurred in the trains simultaneously caused almost 200 victims, and took place three days before the general elections. The Spanish government (Popular Party) attributed the attacks to the Basque terrorist group Euskadi Ta Askatasuna (ETA / Basque Country and Freedom) and tried to maintain this version of the events until the March 14 election with the aim of avoiding any inference that the attack was related to Spanish support for the invasion of Iraq (Michavila 2005).

Different ministers and representatives of the government claimed that the investigation into the attack pointed to the ETA (Basque Country and Freedom) whereas the international community believed that the evidence was more squarely connected to $\mathrm{Al}$ Qaeda (Michavila 2005). Between March 12 and 13, 2004, access to the Internet, electronic messaging and SMS played an important role as a source to contrast the official information (Rodríguez 2004). Citizens could question the credibility of the official version diffused in the traditional media, which presented incongruities with some of the international media (Curiel 2013). News media production and consumption, thus, in this case, became fundamental to contesting the hegemonic narrative of events. In addition, Internet-based and social media communications and connections were used as a channel to summon other citizens to demonstrate in front of the headquarters of the governing Popular Party on March 12, 2004, in Madrid, in an attempt to rebuff government misinformation. These events can be read as an historical milestone in the use of alternative sources/networks/channels of information on the Internet prior to the popularization of social networks (Peñas and Montero 2005). The general election of March 14, 2004, was won by the Socialist Party (PSOE), and led to the presidency of the government by José Luís Rodríguez Zapatero (2004-2011), following eight years of the right-wing Popular Party government.

In another example, on May 15, 2011, only a few days before the Spanish general election, popular citizen demonstrations took place, in which progressive social movements were the protagonists. It all started with an encampment in the Plaza del Sol in Madrid, the nerve center of the city, aimed at denouncing political corruption, high unemployment rates, evictions and austerity measures proposed by the European Union (Calle 2013). The movement quickly gained steam, spreading to other parts of the country. The moment with the greatest participation was on May 21, prior to the beginning of voting. According to the organizers, between 22,000 and 24,000 people were concentrated in the Plaza del Sol and the surrounding areas (Pina 2011), and, at the national level, participation was estimated at some 130,000 participants (Toret 2012).

The activities of this movement were developed through assemblies and work groups that arose spontaneously. They discussed proposals and actions in an attempt to demand of the government a new electoral law with greater citizen participation as 
well as a change in the economic system and improvements in education and basic services (Errejón 2011). The encampment was removed from the Plaza del Sol on June 12. Subsequently, the assembly activities were decentralized to the neighborhoods, developing into cultural and educational centers (Sampedro and Lobera 2014). The Internet played a fundamental role in the preparation, organization and retransmission of the rallies and assemblies. The presence of citizen mobilization on the Internet began in March 2011 with the opening of a Facebook account called Democracia Real Ya (DYA), which currently has more than 400,000 followers. Immediately, Twitter accounts were opened, and videos were produced and disseminated through channels on YouTube and elsewhere. According to data compiled by Alcazan et al. (2012):

On Twitter the most important profiles of the movement are @ democraciareal with more than 118,000 followers, @acampadasol with more than 67,000 and @ acampadabcn with more than 40,000. On Facebook, Democracy Real Ya has 427,000 followers [...] N-1, a free and self-managed social network, which went from having 3,000 users before 15-M to more than 30,000 (Alcazan et al. 2012:62).

For the first time in Spain, alternative information channels were widely used and consulted outside of the traditional means of communication, both private and statecontrolled. Within this realm, the $15 \mathrm{M}$ is a social movement that should be analyzed in the context of other movements, such as the Kitchenware Revolution (2008-2011 in Iceland), the protests in Greece (2010-2012), the Arab Spring, (2010-2013 in Tunisia and Egypt), the Occupy Wall Street movement (2011 in the United States), Yosoy132 (2012 in Mexico) and Passe Livre (2013 in Brazil), which, as Toret (2013) discusses, are:

Movements of new type or network movements are characterized by the contagious emergence and protagonist of protests of citizen networks without previous formal structures, which make intensive and strategic use of digital social networks, mobile telephony and Internet, which take the urban space, and that produce strong and intense affective mobilizations with multiple impacts in a large part of society (Toret 2013:9)

From these $15 \mathrm{M}$ mobilizations, the political party Podemos was created on January 16, 2014. The name of the party comes from one of the slogans of the movement, 'Yes we can'. This political party produced a program for the 2014 European elections that included a wide range of citizen demands that were discussed at its assemblies between May 15 and June 12 in the Plaza del Sol in Madrid, as well as the assemblies they held at other cities of Spain (Jerez et al. 2015). The political program was developed collectively with debates and contributions online as well as through citizen circles in cities, towns and neighborhoods. The demands were of an economic nature, with policies aimed at assisting citizens, not the banking system and financial markets. It also focused on democracy, with proposals for active citizen participation, including in relation to peace within and outside European borders, and also, importantly, touched on the environment and the promotion of sustainability (Podemos 2014). In the 
European elections, which took place four months after the founding of the party, Podemos was positioned as the fifth political force of Spain, obtaining 5 seats and almost $8 \%$ of the vote (European Parliament 2014).

The relatively strong performance for this new and alternative party led to a disinformation campaign by the media that sought to discredit its leaders and reduce its impact on the national political scene (Sampedro 2015). They were accused of irregular financing, including tax evasion, via the governments of Venezuela and Iran, and were discredited by constantly connecting them to President Hugo Chávez of Venezuela. They were also accused of coexistence with the Basque terrorist group ETA (Basque Country and Freedom), and of falsifying data in their academic curricula vitae. Some headlines that exemplify this disinformation campaign against the Podemos party in internationally and nationally recognized media, include:

- 'The Maduro government paid \$272,000 to Pablo Iglesias (the leader of Podemos) in the tax haven of Grenadines in 2014,' published by OkDiario (06/05/2016; see Mercado 2016). This headline was later denied by the newspaper Publico.es, indicating that Iglesias was falsely accused (03/28/2017).

- 'Pablo Iglesias helped the Support Network for ETA prisoners,' published by the newspaper El Mundo (06/30/2014; See Lazaro 2014). This headline and the article omit critical information. The article denounces the participation of leaders of the Podemos party at a dinner of the Herrira group ${ }^{2}$ to talk about conditions for the ETA prisoners (Basque Country and Freedom). However, it omits that other political groups participated in the dinner without any connection to the Podemos party, and that that was a part of a political lobbying strategy used by the Herrira group. On the same day, previous meetings had already been undertaken with other political parties such as the PSOE in Congress for the same purpose (El Diario.es 2014).

Likewise, within Spanish public television (TVE), workers in 2017 denounced censorship practices and the manipulation of information to the detriment of parties in opposition to the Popular Party that governed the country that year (El Periódico 2017).

Fake news and erroneous information, in other cases, may favor political parties, such as the extreme right-wing party VOX. In the regional Parliament of Andalusia elections in 2018, held on December 2, the VOX party won, for the first time, political representation since its creation on December 17, 2013. It obtained 12 seats with almost $11 \%$ of the vote (EL País 2018a). It is not inconceivable to attribute the triumph of that party to fake news about Muslim immigration, gender laws, LGTBQ rights, and laws against gender violence as well as tax laws that were disseminated through social networks and distributed via WhatsApp in the pre-election period (Maldita.es. 2018). A sample of the relationship between fake news about immigration is the image published on the VOX Facebook account, in which the party proposes the deportation of legal immigrants from Spain who have committed crimes, justified with a headline that 'a Senegalese immigrant is arrested in Barcelona for raping an elderly woman of 72 years,' published by the fake news agency CasoAislado (02/18/2019). This image received more than 2000 likes, and was shared more than 500 times. However, no

\footnotetext{
${ }^{2}$ Citizen platform that worked for the rights of Basque prisoners, founded in San Sebastian on February 5 , 2012.
} 
newspaper has taken up this news, nor has it been published on the official sites of the Catalan police.

This electoral campaign, as well as its image management, is consistent with the Brexit campaign in Great Britain, the presidential campaign of Donald Trump in the United States (2016), and the presidential campaign of Jair Bolsonaro in Brazil (2018), all of which were fully lathered with fake, misleading and misrepresented information (Carr et al. in press).

According to Manuel Viejo (2018), after the Andalusian elections, VOX managed to position itself as the party with the most followers on Instagram, more than 120,000 compared with roughly 82,000 for Podemos. VOX has maintained the second place on YouTube with over 60,000 followers, and the third place on Facebook with over 200,000 followers. According to the forecasts of the newspaper El País (2019; see Llaneras 2019), VOX has $11 \%$ support in the polls compared to only $0.2 \%$ obtained in the 2016 elections. This party has introduced into the Spanish political scene propaganda based on stereotypes and fake news that can increase fears, promote xenophobia and racism, and reinforce nationalism and machismo (Cid 2018; Orgaz 2018; SáizPardo 2018). As exemplified in Table 1, VOX representatives disseminated falsehoods in the traditional media, effectively eroding — or attempting to erode - political debate and dialog as a democratic deliberative tool. Misinformation, as seen in this case, is a phenomenon that affects democracy insofar as it can discourage citizens' interest and participation in political debate, processes, decision-making and development, and also

Table 1 News and fake statements in the election campaign in Andalusia 2018.

\begin{tabular}{|c|c|}
\hline Fake News & Distribution medium \\
\hline $\begin{array}{l}\text { The Spanish are out! The public aids for } \\
\text { rent in Madrid are Moroccan and Maghrebi }\end{array}$ & $\begin{array}{l}\text { Newspaper El Matinal (Consulted } \\
\text { on web 03/04/2019) }\end{array}$ \\
\hline $\begin{array}{l}\text { Manifestation this morning in Fuengirola, } \\
\text { Muslims claiming free apartments and financial aid }\end{array}$ & $\begin{array}{l}\text { Via WhatsApp } \\
\text { Maldita.es (11/07/Maldita.es. 2018) }\end{array}$ \\
\hline Muslim assaults Spanish hospital staff & $\begin{array}{l}\text { Via Twitter and published in } \\
\text { Redaccionmedica.com }(03 / 03 / 2018)\end{array}$ \\
\hline $\begin{array}{l}\text { Moroccans, Romanians and Colombians are } \\
\text { already half of prisoners in Spanish prisons }\end{array}$ & $\begin{array}{l}\text { Newspaper Mediterráneo } \\
\text { Digital }(11 / 30 / 2018)\end{array}$ \\
\hline $\begin{array}{l}\text { A school in Terrasa has banned eating ham } \\
\text { 'so as not to offend the Arabs' }\end{array}$ & Newspaper AD Alerta digital (09/24/2018) \\
\hline Fake statements & Distribution medium \\
\hline $\begin{array}{l}\text { The leader of VOX Santiago Abascal, said } \\
\text { weeks ago that the false accusations affected } \\
\text { 'millions of Spanish' and that 'in Spain women } \\
\text { have been murdered mostly by foreigners' }\end{array}$ & $\begin{array}{l}\text { Press conference and via Twitter in } \\
\text { RTVE.es }(01 / 09 / 2019)\end{array}$ \\
\hline $\begin{array}{l}\text { Iván Espinosa, Deputy Secretary of Vox, said that } \\
\text { 'more children killed by their mothers die than } \\
\text { women at the hands of their partners' and } \\
\text { estimated in } 60 \text { children per year the figure. } \\
\text { 'I refer to the data that the president of the } \\
\text { forensic doctors has made public' }\end{array}$ & $\begin{array}{l}\text { TV program Cadena Telecinco } \\
\text { RTVE.es }(01 / 09 / 2019)\end{array}$ \\
\hline
\end{tabular}

This table was constructed by the authors based on information from Maldita.es. (2018) and Martín (2019) 
generate distrust, cynicism and disengagement from the formal electoral system (Serra 2016).

The matter of manipulating reality has to do with fake news, and especially with the phenomenon of misinformation. It is related to the frontier in which language is used to hide, exaggerate or omit in favor of a political and ideological objective (Casas-Mas 2014). In the Spanish political context, there is diverse evidence of the use of disinformation mechanisms by the media (Aguaded and Romero-Rodríguez 2015). In accordance with the ideological and business interests of television networks, a narrative of supposed 'facts' is constructed. Moragas-Fernández and Capdevila (2017) exemplify this phenomenon in their study of the Catalan independence process through the metaphors used in the headlines.

In the case of El País, the option to show the relationship between Catalonia / Spain as a couple relationship where alleged abuse does not entitle the claim to separation, but question the role of the victim, delegitimize the aspirations of Catalonia to become an independent country. The same happens when El Mundo frames these aspirations under the trip / path / movement domain and draws a narrative where independence is synonymous with the abyss, the drift and nothingness. Only La Vanguardia seems to show a certain neutrality in the conflict, shifting the axis of attention to the elections and avoiding the legitimacy of some or other arguments (Moragas-Fernández and Capdevila 2017:30).

In Spain, as in the European Union, measures have been taken to promote the verification of information (El País 2018b). Journalists, and some newspapers, have organized into groups of verifiers such as Maldita.es to counter fake information in formal and informal information networks and channels. At the legislative level, the Spanish Penal Code has introduced penalties for the fake publication of security alerts, insults, slander and scams (Gamon 2017). However, in relation to education and citizenship, progress is scarce. There is no specific formalized subject-area, for example, that is mandatorily and fundamentally interwoven throughout the formal curriculum that works with this type of critical competencies in education. We do acknowledge, however, the burgeoning area, field and network of scholars and educators working on critical media and information literacy. The advances that Spanish educators have made are scattered efforts that have not been able to significantly influence educational policy or the political culture (Cuervo Sanchez and Medrano Samaniego 2013).

\section{A Few Words about the Methodology}

Due to the increasingly significant number of fake news stories, deceptions, images and documents generated daily around the world, fact-checking services have gained importance as a way of guiding citizens regarding the veracity and factuality of the 'news'. In this article, a qualitative and exploratory methodology has been used related to the diffusion of fake news as well as the concomitant repercussions on society/ societies. This has traditionally and almost exclusively been the domain of mainstream media organizations and journalists (in Democracy and Media 1.0) but the widespread 
proliferation and usage of social media has fundamentally altered the context (Democracy and Media 2.0). We have analyzed fake news verifications by some of the newer, Internet-based organizations, including Snopes, PolitiFact, FactCheck.org (USA), Maldita.es (Spain), Paella politics (Italy) and Country (Spain). In addition, we have also consulted some of the more longstanding media outlets that have a newspaper platform as well as an extensive online presence, including the BBC (United Kingdom), Le Monde (France), the New York Times and the Washington Post (United States). Our analysis has involved selecting verified news stories related to immigration in the context of the United States and Europe. We have further isolated certain European countries for the purposes of our study, and also only examined relatively recent stories. We have done so for the following reasons: 1) for more consistent and reliable comparison; 2) to connect more directly with the present context; and 3) the frenzy, awareness and visceral concern around fake news generated through social media is relatively new, notably taking flight during and after the 2016 USA presidential election. With regard to the USA, we selected all checked news stories published by the aforementioned fact-checking services over the period from April 1, 2018 to February 12th, 2019, to coincide with the proliferation of stories and accounts of the immigration flow from the South into the USA. After selecting the verified (fact-checked) news items in our sample, the content of the news was analyzed and the number of news stories related to immigration was quantified. In total, a review of 2412 verifications was conducted as shown in Table 4.

\section{Fake News and Immigration: A Structure Developed in Europe and North America}

\section{The VOX Campaign and Fake News}

As noted, fake news, as well as information manipulation strategies, relies on stereotypes, prejudices and rumors as well as cultural conventions, foibles, vulnerabilities and historical fault-lines to achieve its objectives. In the Spanish case, from the irruption of the VOX (2019) party in the Andalusian elections and its campaign as a government program, a panoply of fake news was developed and orchestrated to influence (some) voters. Typically, fake news is targeted more at some (specific) people and groups but it can ultimately shift debate so as to control issues, discussion and the political landscape. We do not discount here that there are vast social movements and people around the world working on social change and social realities that may not be captured in the mainstream, hegemonic political landscape (Carr and Thésée 2019).

According to the City Council of Barcelona (2012), there are twelve extended stereotypes ${ }^{3}$ about immigration that can affect the social, economic and political life of the country.

1. Arrival of immigrants: 'They are invading us'.

2. Welfare system: 'They take social aid'.

3. Taxes: 'They do not pay taxes'.

\footnotetext{
${ }_{3}^{3}$ These quotes were translated from Spanish to English by the authors.
} 
4. Commerce: 'They receive aid to open shops, they do not inspect them'.

5. Health system: 'They abuse the health emergency services'.

6. Identity: 'We are losing our identity'.

7. Coexistence and civility: 'They do not know the rules, and they are uncivilized'.

8. Housing: 'They live huddled together and lower the level of the floors'.

9. Educational system: 'They lower the level in the schools'.

10. Public space: 'They occupy and misuse the public space'.

11. Work and training: 'They have no training. They take away work'.

12. Integration: 'They are a burden, and do not want to integrate'.

The network of Spanish journalists and news-verifiers comprising Maldita.es. (2018) has investigated and uncovered several fake news stories that were disseminated through social media networks and online newspapers within a project called 'damn migration'. This project is exclusively dedicated to checking news and statements in social networks/media and newspapers within the Spanish territory. In several of the news stories verified during the Andalusian electoral campaign period, it is possible to identify the anti-migratory and anti-Muslim bias embedded within the narrative, discourse and imagery. Table 1 presents examples of some fake news disseminated during the Andalusian campaign, as well as some statements made by the VOX party leaders.

In spite of these types of false/fake declarations, highlighted in Table 1, the VOX party has been able to enact proposals and measures that attack the rights of minorities. In particular, it has had the opportunity to propose excessive laws against the immigrant population in Spain, such as the expulsion of 52,000 people (Cid 2018). At the same time, the populist discourse in Andalusia is permeating other right-wing parties in Spain, connecting with the legacy and ideology of the fascist era of Franco (El País 2018a; Viejo 2018).

For an analysis of the influence of fake news and misinformation in relation to Spanish politics and citizenship, it would be important to document the information habits, experiences and perspectives of the consumers and producers of media as well as through social media. According to a study by Negredo et al. (2018), Spaniards get their news from a variety of sources but the Internet and social media are becoming increasingly important: $85 \%$ get news from online sources, including social media platforms; $76 \%$ from watching TV; $60 \%$ through social media platforms; and $51 \%$ use print sources as a way to get informed. Moreover, 53\% of users acknowledged sharing news via social media, and more than $30 \%$ indicated that they comment on the news online. Of course, these figures serve as a guideline and trendline more so than the definitive portrait of a very fluid situation but we do believe that social media, undoubtedly, is taking up more space in how people connect, engage with and learn about the world. This also goes for similar data provided for the USA situation below.

The official, formal mainstream press can inform us of widely-accepted (normative and hegemonic) or disseminated views on immigration. According to data collected from 23 Spanish newspapers in 2018 by the media observatory SOS Racisismo de Gipuzkoa, the main themes related to immigration were pateras and detention areas. In other words, the focus was on the exceptional aspects of immigration. In Table 2, we highlight how the mainstream news underscored primarily the negative aspects of 
Table 2 Primary topics on immigration presented in Spanish newspapers in 2018.

Most prominent items.

Pateras and detention areas

Seeking refuge

Opinions on regulating immigration

Other spaces: leisure and communication

Extreme right

Detention and expulsion of immigrants

Number of newspaper articles published in 2018

3973

1703

1049

908

764

699

The data and categories are prepared and published by the Media Observatory of SOSRacismo Gipuzkoa (2018)

immigration, de-emphasizing human rights, co-existence and the benefits of immigration.

\section{Anti-Immigration Speech, False News and Credible Statements: Europe and North America}

The incursion of VOX into Spanish politics is not a novelty in Europe; rather it can be analyzed as a consequence of an anti-system (anti-normative democracy) discourse led by extreme-right parties in which anti-immigration sentiment is cultivated, tapped into and operationalized at the political level, and also, concurrently, seeping into the economic and cultural realms (PorCausa 2018). Concerning economics, there are prejudices, stereotypes and discrimination related to the loss of employment, reduction of salaries, and refusal to accord welfare for immigrants. Within the cultural context, imagery evoking an invasion, the imposition of foreign values, especially in relation to 'Muslim' culture, sexist attitudes and increased crime have become a staple to mainstream debates. Of course, this model parallels the situation elsewhere within Europe and North America, including in fake news reports in Great Britain, France and Italy. Table 3 presents some fake news statements by right-wing politicians that were verified and de-bugged by various media. Such stories paint an excessively negative portrait of the immigrants, especially in relation to the Muslim population.

This type of discourse places immigrants in a singular, deficient group, ignoring the origins and context of why they were seeking asylum and refuge as well as their rights. The migratory incursion into European politics within the digital era is summarized in a report prepared by PorCausa.org (2018):

The Amnesty International Annual Report 2016/2017 highlights the potential of the rhetoric of hatred, of the "us against them" to which a long list of leaders who have "self-described anti-system and wield a policy of demonization it harasses, turns scapegoats and dehumanizes entire groups of people to obtain the support of the electorate". This exclusionary and xenophobic rhetoric has acquired a generalization not seen since the interwar period, with the Internet as fuel for the propagation of populist, hate, false and hoax messages that try to disguise themselves as freedom of expression but that feed a toxic narrative "impossible to isolate" (PorCausa.org 2018:12). 
Table 3 Fake news and misleading stories in Europe

\begin{tabular}{|c|c|}
\hline Media outlet and date & News story found to be fake \\
\hline $\begin{array}{l}\text { BBC (Great Britain) } \\
(09 / 13 / 2018)\end{array}$ & $\begin{array}{l}\text { The deputy leader of the far-right party Alternative } \\
\text { for Germany (AfD) said there had been " } 447 \\
\text { killings and murders" by illegal migrants in } \\
\text { Germany last year. }\end{array}$ \\
\hline $\begin{array}{l}\text { Le Monde (France) } \\
(02 / 14 / 2017) \text { (See Sénécat 2017) }\end{array}$ & $\begin{array}{l}\text { "All terrorists are immigrants": the poisoning of } \\
\text { MEP Nicolas Bay. }\end{array}$ \\
\hline $\begin{array}{l}\text { Le Monde (France) }(11 / 2 / 2015) \text { See Laurent } \\
\text { 2015) }\end{array}$ & $\begin{array}{l}\text { The republican deputy of Paris guarantees that a } \\
\text { refugee receives } 700 \text { euros a month in France, more } \\
\text { than a modest family. }\end{array}$ \\
\hline $\begin{array}{l}\text { Pagella Politica (Italy) } \\
(12 / 24 / 2018)\end{array}$ & $\begin{array}{l}\text { In the United Kingdom some Muslim refugees have } \\
\text { called for the banning of dogs "out of respect for Islam" }\end{array}$ \\
\hline $\begin{array}{l}\text { Pagella Politica (Italy) } \\
(01 / 30 / 2019)\end{array}$ & $\begin{array}{l}\text { Macron: Italy deserves all immigrants because it was a } \\
\text { fascist country (Published on Facebook) }\end{array}$ \\
\hline $\begin{array}{l}\text { Pagella Politica (Italy) } \\
(02 / 21 / 2019)\end{array}$ & $\begin{array}{l}\text { A security guard killed in Rome by a black man } \\
\text { (Published on Facebook) }\end{array}$ \\
\hline $\begin{array}{l}\text { Snopes (USA) } \\
(02 / 29 / 2017)\end{array}$ & $\begin{array}{l}\text { A "Muslim migrant' beats up a boy on crutches in a } \\
\text { video posted to a site in the Netherlands. }\end{array}$ \\
\hline Le Vif (Belgium) (10/02/2017) & $\begin{array}{l}\text { Immigrants: producing green electricity to earn } 24 \mathrm{~h} \text { of } \\
\text { legality }\end{array}$ \\
\hline
\end{tabular}

Elaborated by the authors by consulting various sources as: BBC (2018); Humbeeck (2017); Laurent (2015); Sénécat (2017); Pagella Politica (2018, 2019a, 2019b); Snopes (2017)

A clear example of this vilification process of immigrants is the militarization of the Mediterranean Sea to combat migratory flows through Operation 'Triton,' whose main objective was to destroy the boats of human-traffickers departing from the African coast. In 2015, the European Commission, in an extraordinary meeting in Luxembourg, decided to triple the annual budget of this operation, as well as granting a safe country status to Turkey, Lebanon and Jordan. That is, a military and political strategy had been developed to prevent the refugee population from approaching the borders of European countries (Oroza Busutil and Puente Márquez 2017). This is a reformulation of the border policy in Europe, responding to the protectionist ideas of the European states, which essentially ignores some of the fundamental tenets of human rights. Thus, at present, the rights to asylum and refuge, which were enshrined and upheld in the postSecond World War period, implementing the Charter of the United Nations and the Universal Declaration of Human Rights (1948) and the Convention of Geneva (1951), have lost (some of) their validity. Some rights that were proclaimed when it was the European population that suffered the consequences of war have now been re-conceptualized. Human-beings continue to drown in the Mediterranean Sea in their quest to make it to Europe. In 2018, according to UNHCR (2018), some 2000 died attempting the journey, and roughly 14,000 migrants are in Libyan prisons in deplorable conditions, mired in a quagmire in the hopes of seeking exile in Europe (Galarraga 2018).

Similarly, in North America, this type and structure of fake news, like in Europe, has been exploited by political parties and representatives. In the United States, President Trump has been obsessively engaged with the marketing of fake, misleading and 
nefarious statements (Allcott and Gentzkow 2017; Moffitt 2018). According to Graves and Jenkins (2018), by presenting how American people have been getting news from the Internet on Reuters Institute Digital News Report (2018): more than 70\% of Americans were reported to use online sources of news, including social media; almost $60 \%$ of Americans get news from TV; some $45 \%$ get informed by social social media platforms, and $21 \%$ claimed to get their news from print news. As for sharing news with others, $35 \%$ of people interviewed claimed to share news via social media or email, and $24 \%$ indicated that they commented on news via social media or through websites.

Moreover, regarding the most utilized social media platforms and their role as news disseminators in the USA in 2018, Facebook leads the list with almost $70 \%$ of Americans, with almost $40 \%$ using if for the news. The Youtube platform comes in second place, and Twitter placed third. Reading, searching and disseminating news was an important feature of all of these platforms (see Graves and Jenkins 2018). In comparative terms, the USA has the highest number of Twitter users, followed by India, with the reverse being the case for Facebook users. Most American Facebook users are in the 18-44 age-group. In 2017, the third most popular activities of American Facebook users were: send private messages to friends or family $(66 \%)$, sharing personal photos or videos $(55 \%)$, and reading or sharing news (52\%) (Statista 2019).

One of the most frequent themes in social media and news in 2018 and early 2019 was immigration, following the 'Caravan' from Central America that continued North to the US border. According to USAFACTS (2019), in analyzing the annual USA State of Union addresses in relation to the words/themes most expressed by the current president and former presidents, the word immigration (or words related to this topic) was prominently mentioned. In 2018, Donald Trump mentioned immigration almost 80 times for every 10,000 word in his speech. In his early 2019 State of the Union address, Trump uttered the word almost 100 times for every 10,000 words (Feldman 2019).

By verifying some of the American fact-checking services, such as PolitiFact, Snopes and Fact.Check.Org as well as newspapers such as the New York Times and Washington Post, from April 2018 to February 2019, we are able to get a sense of how the immigration debate is being (and might be) shaped. There were several topics related to immigration that were contentious, and could have contained misleading and fake information, including: the separation of 'illegal' children from their parents at the USA border, the Central American 'Caravan,' and the truth around the need and the

Table 4 Fake and misleading stories checked from April 1, 2018, to February 12, 2019.

\begin{tabular}{lcc}
\hline Fact-checking organization & Number of all checked news stories & $\begin{array}{l}\text { Number of checked news } \\
\text { stories related to immigration }\end{array}$ \\
\hline Politifact & 280 & 49 \\
Snopes & 1363 & 105 \\
FactCheck.Org & 431 & 33 \\
NY Times & 128 & 37 \\
Washington Post & 210 & 42 \\
\hline
\end{tabular}

Elaborated by authors using the following resources: FactCheck.Org (2018-2019, NYTimes (2018-2019), Politifact (2018-2019), Snopes (2018-2019), Washington Post (2018-2019) 
reality of the construction of the proposed border wall. We present the table below (Table 4), which quantifies all checked news by fact-checking services and newspapers online in an effort to identify the level of interest in this area for this particular story or theme.

Interestingly, within this context it can be shown that fake news is a propaganda practice that simplifies the arguments about reality and that discourses that are involved. In other words, the effect is to manipulate reality to the detriment of deliberation and participatory citizenship within democracy (Table 5).

\section{Conclusion: Re-Thinking Citizen Participation and Democracy in the Light of Fake News}

As we have outlined throughout this article, fake news is a long-standing phenomenon in and around the world, and the issue has come into a higher level of prominence with the onset of the digital revolution and social media. The concern over how people/citizens can prepare for engaging with fake news is fundamental, and what happens in and through education should be closely considered (Carr and Thésée 2019). We are particularly concerned about citizens being duped, betrayed and led to battle over fabricated, misrepresented and misleading motives, practices, productions and propaganda.

Fake news is mainly and widely spread/diffused by social media platforms, and there are few systemic, formalized, critical educational programs aimed at deciphering the veracity of the news and information (Carr et al. 2018). (Fregoso 2018: 5) compares social media platforms to a 'hydra,' the Greek mythological animal of nine heads ('tackle one and another one pops up to take its place'). In other words, the more you try to deal with it, the more it multiplies in complexity, nuance, contour and quantity.

Regarding the role of education in combating the internalization, usage and uncritical dissemination of misinformation and fake news, there is no complete handbook or unfettered checklist designed to cope with fake news, although it is possible to develop some core principles and strategies. In an era where truth is played like a bluffing game, the first and most important principle in facing misinformation is to encourage and cultivate critical thinking and engagement in and through education (Carr and Thésée 2019). We are drawn to John Dewey (2001) and Paulo Freire's (1970) legacy and work, underscoring the dialectical relationships, the formal-informal and school-community interplay, the subtle nuanced manifestations of inequitable power relations, the process of conscientization and the unending quest for political literacy and critical engagement. Teaching and learning, within this theoretical and conceptual framework, blends over, through and beyond the formal learning process, teacher-student relations and pedagogy, and concerns as well a broader focus on social justice, social inequalities, power relations, and race/class/gender and other socially constructed identities and lived experiences.

Westheimer (2018) recognizes the importance of encouraging critical thinking in the digital area, pointing out some ideas that should be addressed by educators: a) Teach students to ask questions in order to avoid building a totalitarian society wherein there is the notion of a single truth, and they should not avoid controversial problems; b) Expose students to multiple perspectives to ensure that they do not believe that their reality is universal; and c) Focus on the local community, making connections global, and encouraging civic engagement. What students read and hear about should be discussed and 
Table 5 Fake and misleading stories about immigration in the USA.

\begin{tabular}{|c|c|c|c|}
\hline $\begin{array}{l}\text { Fake/ misleading } \\
\text { stories. }\end{array}$ & Social media & $\begin{array}{l}\text { Content of misleading } \\
\text { the information }\end{array}$ & Fact-checking \\
\hline
\end{tabular}

\begin{tabular}{|c|c|c|}
\hline $\begin{array}{l}\text { A Specific Law } \\
\text { Mandate Family } \\
\text { Separation and } \\
\text { Detention of } \\
\text { Minors }\end{array}$ & $\begin{array}{l}\text { Spread mainly by } \\
\text { Facebook users }\end{array}$ & $\begin{array}{l}\text { Shared images as a part of the } \\
\text { Public Law 107-296 as a } \\
\text { vague indication that chil- } \\
\text { dren are allowed to be sepa- } \\
\text { rated from their families, } \\
\text { and, moreover, claiming that } \\
\text { this change in law was led by } \\
\text { the Democratic Party in the } \\
\text { USA. }\end{array}$ \\
\hline
\end{tabular}
Immigrant Children Spread mainly by in Orange Jumpsuits
Facebook users
Mexican official Spread mainly by being dragged by Facebook users the caravan
Misleading Border Crime Statistic
President Trump's claim

The Caravan, the CDC and a False Flight

\section{Shared images as a part of the Public Law 107-296 as a vague indication that chil- dren are allowed to be sepa- rated from their families, and, moreover, claiming that this change in law was led by the Democratic Party in the USA.}

One image attributed to immigrants who took part in the Central American Caravan shows several men with bandanas over their mouths dragging a Mexican police officer.

Trump claimed that 17,000 individuals with criminal records were arrested by USA officials at the Southern border in 2018.

Spread by the website Right of the Right and shared on Facebook
The following false story was shared by the website Right of the Right: "a plane registered to the Center for Disease Control landed in San Diego to pick up diseased migrants at the border to fly them to Georgia where they will receive medical care paid for by the U.S. taxpayers." [From Right
This law was approved in 2002, under a Republican majority. The content of the law was misrepresented, according to Lacapria (2018a): the law 'made no provision for separating a child from parents or legal guardians or for detaining any child separated by DHS agencies from their parent, and it was primarily passed by Republicans'.

(Story checked in June 2018)

Indeed, the fake image is a part of a previous news story that accompanied an article about school and prisons, published by Californians for Safety and Justice in 2014 (Lacapria 2018b)

(Story checked in June 2018)

It is a misinformed image taken in 2014 when a clash with the Mexican police took place in Acapulco (Spencer 2018)

(Story checked in November 2018)

According to Gore (2019), the U.S. president has not considered the whole portrait of this information. In fact, about 17,000 individuals with criminal records tried to enter the USA but not all of those people attempted to enter illegally through the Southwest border in 2018.

(Story checked in January 2019)

The supposed flight, actually, was a flight from San Diego, California, to Fort Benning, Georgia, and it was not registered to the Center for Disease Control.

(Story checked in December 2018) 
Table 5 (continued)

\begin{tabular}{|c|c|c|c|}
\hline $\begin{array}{l}\text { Fake/ misleading } \\
\text { stories. }\end{array}$ & Social media & $\begin{array}{l}\text { Content of misleading } \\
\text { the information }\end{array}$ & Fact-checking \\
\hline
\end{tabular}

of the Right (2018), cited by

Fichera 2018]

Elaborated by the authors using diverse sources, including: Gore (2019); Fichera (2018); Lacapria (2018a); Lacapria (2018b) and Spencer (2018)

questioned, and this should be particularly important with the quickly evolving social media interactions that most young people are exposed to. A basic question at this stage is: how do education systems conceptualize and develop critical media literacy, how do they implement it, and what do they do to ensure that hegemonic shaping of serious issues can be grappled with as well as being contested? Our concern with critically-engaged citizen education is intertwined with a robust critically-engaged education.

Returning to Spain and elsewhere, in relation to fake news, electoral politics and immigration, we note that the toxic narrative against immigration has resulted in xenophobic political platforms, policy initiatives, a call to reinforce borders and other measures. Populism now appears to be interlaced with the vilification of the 'other,' concomitant with a punishing media and social media campaign that fully extends mainstream discourse and cultural mores. In the quest for electoral success, sophisticated campaigns involving fake news, propaganda, misinformation and disinformation became a backbone to the overall strategy to limit and/or eliminate immigration, or significantly affect those labeled 'immigrants'. We are also fully cognizant that not all 'immigrants' are considered and treated equally, and that the racial, religious and other deeply-ingrained tones lent to this debate disproportionately affect some more than others.

Confronting fake news, as well as misinformation, is a task that needs intersectoral work among the state, non-governmental organizations, civil society, education and citizens as well as other sectors. The state must provide legal and social support to combat and contextualize misinformation. Thus, it must adopt laws that penalize misinformation and lies while being vigilant to not inculcate censorship, which is not an easy task. An example of this is the Action Plan against Disinformation presented by the European Council (2018), based on four pillars: (i) improving the capacities of the institutions of the Union to detect, analyze and expose disinformation; ii) strengthening of coordinated and joint responses to misinformation; (iii) mobilize the private sector to address misinformation; iv) create awareness and improve the resilience of society (5).

Another example is found in Spain with the proposal of the current PSOE government before the April 28, 2019, general election. An inter-institutional group has been created involving the Department of National Security, the State Secretariat of Communication and the Ministries of Interior, Defense and Foreign Affairs to identify and remedy fake news prior to the election. That is, fake news has been identified as a threat to national security for this government (Abellán 2019).

Of course, we are concerned about Government leading (all) initiatives, although we do see a role that it can and should play. The Assange case, which is quickly evolving during the writing of this article, will most likely have a significant impact on media, journalism, social media and the meshing into Democracy 3.0, which involves enhanced algorithms, surveillance, control and oversight. Citizen participation must 
grapple with the nuances and truncheon of hegemonic forces that interweave themselves through 'formal' democracy, 'formal' education and 'formal' engagement, and social media usage will undoubtedly be a part of this evolving landscape.

Aknowledgments We thank the two anonymous reviewers for their helpful comments as well as those of the editors of this special issue. We also acknowledge and thank the Canadian Social Science and Humanities Research Council for its funding in the form of a grant entitled Social Media, Citizen Participation and Education (\#435-20170745), for which the first author is the Principal Investigator. Lastly, the authors wish to thank two other colleagues, in particular, for their support and ongoing collaboration, Michael Hoechsmann and Gina Thésée.

Open Access This article is distributed under the terms of the Creative Commons Attribution 4.0 International License (http://creativecommons.org/licenses/by/4.0/), which permits unrestricted use, distribution, and reproduction in any medium, provided you give appropriate credit to the original author(s) and the source, provide a link to the Creative Commons license, and indicate if changes were made.

\section{References}

Aguaded, I., \& Romero-Rodríguez, L. M. (2015). Mediamorfosis y desinformación en la infoesfera: Alfabetización mediática, digital e informacional ante los cambios de hábitos de consumo informativo. Education in the Knowledge Society, 16(1), 44-57.

Alcazan, A., Axebra, Q., Levi, S., Sunotissima, T., \& Toret. (2012). Tecnopolítica, Internet y R-evoluciones. Sobre la centralidad de las redes digitales en el \#15M. Barcelona: Icaria.

Allcott, H., \& Gentzkow, M. (2017). Social media and fake news in the 2016 election. Journal of Economic Perspectives, 31(2), 211-236.

BBC News Europe. (2018) Reality Check: Are migrants driving crime in Germany? (September 13). https://www.bbc.com/news/world-europe-45419466. Accessed 29 June 2019.

Beevor, A. (2012). The Battle for Spain: The Spanish civil war 1936-1939. UK: Hachette.

Braun, M. J., \& Henderson, G. L. (2016). Propaganda and rhetoric in democracy: History, theory, analysis. Carbondale: Southern Illinois University Press.

Calle, Á. (2013). El 15-M y la transición necesaria. Barcelona: Icaria.

Carr, P. R., \& Thésée, G. (2019). “It's not education that scares me, it's the educators... ": Is there still hope for democracy in education, and education for democracy? Gorham, ME: Myers Education Press.

Carr, P. R., Hoechsmann, M., \& Thésée, G. (Eds.). (2018). Democracy 2.0: Media, political literacy and critical engagement. Rotterdam: Brill/Sense.

Carr, P. R, Daros, Michelli, Cuervo, S \& Thésée, G. (in press). Faking the re-awakening: Social media and the quest for democracy. In Trifonis, Peter (ed.), International Handbook of Cultural Studies and Education Reader. New York: Springer.

Casanova, J., \& Andres, C. G. (2009). Historia de España en el siglo XX. Madrid: Ariel.

Casas-Mas, B. (2014). Infoxicación a través de los medios de comunicación. Ámbitos: Revista Internacional de Comunicación, 24, 1-11.

CasoAislado. (2019) Detienen en Barcelona a un inmigrante senegalés por violar a una anciana de 72 años. CasoAislado. (February 18) https://casoaislado.com/detienen-a-un-inmigrante-senegales-en-barcelonapor-violar-a-una-anciana-de-72-anos/

Cid, G. (2018) El arma secreta de Vox en la red: así cazó votos por WhatsApp en su campaña electoral. El confidencial (December 3) https://www.elconfidencial.com/tecnologia/2018-12-03/arma-secreta-voxwhatsapp-camapanas_1683286/. Accessed 29 June 2019.

City Council of Barcelona (2012). Estrategia para combatir rumores y estereotipos sobre diversidad. http://www.bcnantirumors.cat/. Accessed 29 June 2019.

Cuervo Sanchez, S. L., \& Medrano Samaniego, C. (2013). Literacy in the media: Beyond the competence development. Teoria de la Educacion, 25(2), 111-131. 
Curiel, E. H. (2013). Periodistas y redes sociales en España: del 11M al 15M (2004-2011). In Doctoral dissertation. Madrid: Universidad Carlos III de Madrid.

Dewey, J. (2001). Democracy and education. Hazleton: The Pennsylvania State University.

El Diario.es. (2014) Podemos denuncia que se utilice el terrorismo como arma arrojadiza contra Iglesias. El Diario.es (June 30) https://www.eldiario.es/politica/Podemos-critica-terrorismo-arrojadizaZapatero_0_276472566.html. Accessed 29 June 2019.

El País (2018a) Análisis del vuelco electoral en Andalucía. El País (December 03) https://elpais. com/elpais/2018/12/03/media/1543837521_961840.html. Accessed 29 June 2019.

El País (2018b) Ofensiva de UE contra las noticias falsas. El País (December 09) https://www.elpais.com. uy/mundo/ofensiva-ue-noticias-falsas.html Accessed 29 June 2019.

El Periódico (2017) Los periodistas de TVE denuncian que la "manipulación" va en aumento. El Periódico (August 11) https://www.elperiodico.com/es/tele/20170811/consejo-de-informativos-tve-denunciacrecimiento-manipulacion-6219611 Accessed 29 June 2019.

Errejón, Í. (2011). El 15-M como discurso contrahegemónico. Encrucijadas-Revista Crítica de Ciencias Sociales, 2, 120-145. Accessed 29 June 2019.

European Council. (2018). Action plan against disinformation. Bruselas: European Commission https://ec. europa.eu/commission/publications/action-plan-disinformation-commission-contribution-europeancouncil-13-14-december-2018_en. Accessed 29 June 2019.

European Parliament. (2014) Resultados de las elecciones europeas 2014. Resultados por país: España. Recuperado de http://www.europarl.europa.eu/elections2014-results/es/country-results-es-2014.html. Accessed 29 June 2019.

FactCheck.Org. (2018-2019) Archives. Immigration 2018-2019. Retrieved from https://www.factcheck. org/issue/immigration/. Accessed 29 June 2019.

Feldman, S. (2019). State of the union. Immigration runs Trump's state of the union. The statista portal (February 7) https://www.statista.com/chart/16923/trump-immigration-sotu/

Fichera, A. (2018). The caravan, the CDC and a false flight. Factcheck (December 3) https://www.factcheck. org/2018/12/the-caravan-the-cdc-and-a-false-flight/. Accessed 29 June 2019.

Fleming, J. (2014). Media literacy, news literacy, or news appreciation? A case study of the news literacy program at Stony Brook University. Journalism \& Mass Communication Educator, 69(2), 146-165.

Fregoso, J. (2018) \# Mexico2018 "fake News"and social media. The News Heads of the Hydra. Reuters Institute, University of Oxford. https://reutersinstitute.politics.ox.ac.uk/sites/default/files/2018-06 /Mexico2018\%20Fake\%20News\%20and\%20Social\%20Media\%20The $\% 20$ New $\% 20$ Heads $\% 20$ of $\% 20$ the\%20Hydra 0.pdf. Accessed 29 June 2019.

Freire, P. (1970). Pedagogy of the oppressed. New York: Continuum.

Galarraga, N. (2018) El 'Aquarius' abandona el rescate de migrantes tras una dura campaña de hostigamiento institucional. El Pais (December 7) https://elpais.com/internacional/2018/12/07 /actualidad/1544186094_956589.html. Accessed 29 June 2019.

Gamon, V. P. (2017). Internet, la nueva era del delito: ciberdelito, ciberterrorismo, legislación y ciberseguridad. URVIO, Revista Latinoamericana de Estudios de Seguridad, 20, 80-93.

Gore, D. (2019) Video: Criminals Arrested at Southern Border. Factcheck (January 11) https://www.factcheck. org/2019/01/video-criminals-arrested-at-southern-border/

Graves, L., \& Jenkins, J. (2018). Digital News Report United States, 2018 Retrieved from http://www. digitalnewsreport.org/survey/2018/united-states-2018/. Accessed 29 June 2019.

Haidar, J. (2018). Las falacias de la posverdad: desde la complejidad y la transdisciplinariedad. OXÍMORA Revista Internacional de Ética y Política, 13, 1-16. https://doi.org/10.1344/oxi.2018.113.22330

Humbeeck, B. V. (2017) Migrants : produire de l'électricité verte pour gagner 24 heures de légalité. Retrieved from https://www.levif.be/actualite/belgique/migrants-produire-de-l-electricite-verte-pour-gagner-24heures-de-legalite/article-normal-732157.html? cookie_check=1550789914.

Ibisate, F. J. (2018). Bush II y la crisis del multilateralismo. Realidad: Revista de Ciencias Sociales y Humanidades, 103, 19-50.

Jensen, R. (2016) Writing Dissent in Propaganda Flood. In: Braun, M. J., \& Henderson, G. L. (2016). Propaganda and rhetoric in democracy : History, theory, analysis. Carbondale: Southern Illinois University Press.

Jerez, A., Maceiras, S. D. A., \& Maestu, E. (2015). Esferas públicas, crisis política e internet: el surgimiento electoral de Podemos. História, Ciências, Saúde-Manguinhos, 22, 1573-1596.

Kleemans, M., \& Eggink, G. (2016). Understanding news: The impact of media literacy education on teenagers' news literacy. Journal of Education, 5(1), 74-88.

Lacapria, K. (2018a). Does a specific law mandate family separation and detention of minors? Snopes (June 19) https://www.snopes.com/fact-check/does-law-family-separation-detention-minors/. 
Lacapria, K (2018b). Are These Immigrant Children in Orange Jumpsuits? Snopes (June 11) https:/www. snopes.com/fact-check/are-children-orange-jumpsuits/. Accessed 29 June 2019.

Laurent, S. (2015) Réfugiés et aides sociales : les intox de Pierre Lellouche. Le Monde (novembre 2) https://www.lemonde.fr/les-decodeurs/article/2015/11/02/refugies-et-aides-sociales-les-intox-de-pierrelellouche_4801590_4355770.html. Accessed 29 June 2019.

Lázaro, F. (2014) Pablo Iglesias ayudó a la red de apoyo a los presos de ETA. El Mundo (June 30) https://www.elmundo.es/espana/2014/06/30/53b06a85e2704e2e3a8b4579.html. Accessed 29 June 2019.

Llaneras, K. (2019), Lo que dicen las encuestas para las elecciones generales. El País (February 14) https://elpais.com/politica/2019/02/13/actualidad/1550063083_680240.html. Accessed 29 June 2019.

Maldita.es. (2018). Maldita inmigración. Proyecto. Retrieved from https://migracion.maldita.es/por-que-esteproyecto/. Accessed 29 June 2019.

Maraña, J. (2018) Las verdaderas fake News. InfoLibre (march 16) https://www.infolibre. es/noticias/opinion/columnas/2018/03/16/verdaderas_fake_news_80723_1023.html. Accessed 29 June 2019.

Martín, A. (2019) Los bulos y desinformaciones de Vox sobre la violencia machista y su mezcla con la violencia doméstica. RTVE.es (January 09) http://www.rtve.es/noticias/20190109/bulosdesinformaciones-vox-sobre-violencia-machista-su-mezcla-violencia-domestica/1865821.shtml. Accessed 29 June 2019.

Martín Rojo, L. (2007). Discursos en guerra. Crónicas y humor político en torno a la ocupación de Irak. Discurso \& Sociedad, 1(4), 575-603.

Mercado, F. (2016) El gobierno de Maduro pagó 272.000 dólares a Pablo Iglesias en el paraíso fiscal de Granadinas en 2014. OkDiario (June 05) https://okdiario.com/investigacion/policia-investiga-pago-272000-dolares-pablo-iglesias-gobierno-venezuela-124602

Michavila, N. (2005). Guerra, terrorismo y elecciones: incidencia electoral de los atentados islamistas en Madrid. Boletín Elcano, 63, 34.

Moffitt, B. (2018). Populism 2.0: Social media and the false allure of 'unmediated'representation. In G. Fitzi, J. Mackert, \& B. S. Turner (Eds.), Populism and the crisis of democracy volume 2: Politics, social movements and extremism (pp. 30-46). London: Routledge.

Moragas-Fernández, C. M., \& Capdevila, A. (2017). La mediatización del proceso independentista de Cataluña: el rol de la metáfora en tratamiento informativo de El Mundo, El País y La Vanguardia. Revista Dígitos, 2(3), 11-36.

Negredo, S., Amoedo, A., Vara, A., (2018). Digital News Report Spain 2018. http://www.digitalnewsreport. org/survey/2018/spain-2018/. Accessed 29 June 2019.

Núñez, R. (2018). Los efectos de la posverdad en la Democracia//the effects of post-truth politics on democracy. Revista de Derecho Político, 1(103), 191-228.

NYTimes (2018-2019). Fact Checks 2018-2019. https://www.nytimes.com/spotlight/fact-checks. Accessed 29 June 2019.

Orgaz, C. (2018). Vox: cómo es el primer partido de ultraderecha que llega a un parlamento en España en los últimos 36 años (y por qué genera polémica). $B B C$ (Decembre 04) https://www.bbc.com/mundo/noticiasinternacional-46434230. Accessed 29 June 2019.

Oroza Busutil, R., \& Puente Márquez, Y. (2017). La crisis migratoria en el Mediterráneo y la Unión Europea: principales políticas y medidas antinmigrantes. Revista Novedades en población, 13(26), 1-9.. Accessed 29 June 2019.

Pagella Politica (2018). Foto decontestualizzata e titolo falso: musulmani contro i cani nel Regno Unito. Pagella política (December 24) https://pagellapolitica.it/bufale/show/247/foto-decontestualizzata-e-titolofalso-musulmani-contro-i-cani-nel-regno-unito. Accessed 29 June 2019.

Pagella Politica (2019a). Notizia falsa: Macron: "L'Italia merita tutti i migranti perché era un Paese fascista" Pagella política (February 14) https://pagellapolitica.it/bufale/show/317/notizia-falsa-macron-litaliamerita-tutti-i-migranti-perch\%C3\%A9-era-un-paese-fascista. Accessed 29 June 2019.

Pagella Politica (2019b) La notizia falsa della guardia giurata uccisa a Roma da un uomo nero Pagella política (February 21) https:/pagellapolitica.it/bufale/show/350/la-notizia-falsa-della-guardia-giurata-uccisa-aroma-da-un-uomo-nero. Accessed 29 June 2019.

Peñas, I. L., \& Montero, J. R. (2005). Los mecanismos del cambio electoral del 11-M al 14-M. Claves de razón práctica, 149, 36-45.

Pina, A. (2011) La toma de la Puerta del Sol en Madrid: crónica del movimiento social 15-M. Métropolitiques (June 13) https://www.metropolitiques.eu/La-toma-de-la-Puerta-del-Sol-en.html. Accessed 29 June 2019.

Pobes, C. R., \& de Maturana Diéguez, V. L. (2018). Nuevas perspectivas sobre el estudio de la Guerra Civil en el País Vasco. Sancho el sabio: Revista de cultura e investigación vasca, 1, 7-12. 
Podemos. (2014). Programa del Cambio. https://podemos.info/wp-content/uploads/2015/05/prog_marco_12. pdf. Accessed 29 June 2019.

Politifact. (2018-2019). Statements we say are false. 2019-2018. Retrieved from https://www.politifact. com/truth-o-meter/rulings/false/. Accessed 29 June 2019.

PorCausa, O. R. G. (2018). Anti-inmigración. Informe: El auge de la xenofobia en Europa https://porcausa. org/wp-content/uploads/2017/10/Antinmigracion_El_auge_de_la_xenofobia_populista_Europa_ febrero_2018.pdf. Accessed 29 June 2019.

Rodríguez, P. (2004). 11-M-Mentira de Estado: Los tres días que acabaron con Aznar. Grupo Zeta: Ed. B.

Sáiz-Pardo, M. (2018) Los mensajes que Vox calca a la ultraderecha europea. Sur (Decembre 03) https://www. diariosur.es/elecciones/andaluzas/vox-ultraderecha-europea-20181203122546-ntrc.html. Accessed 29 June 2019.

Sampedro, V. (2015). Podemos, de la invisibilidad a la sobre-exposición. Teknokultura, 12(1), 137-145. https://doi.org/10.5209/rev_TK.2015.v12.n1.48890

Sampedro, V., \& Lobera, J. (2014). The Spanish 15-M movement: A consensual dissent? Journal of Spanish Cultural Studies, 15(1-2), 61-80. https://doi.org/10.1080/14636204.2014.938466

Sénécat, A. (2017) Tous les terroristes sont des immigrés: l'intox du député européen FN Nicolas Bay. Le Monde (February, 14) https://www.lemonde.fr/les-decodeurs/article/2017/02/14/tous-les-terroristes-sontimmigres-1-intox-du-depute-europeen-fn-nicolas-bay_5079530_4355770.html. Accessed 29 June 2019.

Serra, G. (2016). Comprar, coaccionar y desinformar al votante. Problemas duraderos de la democracia mexicana. Política y gobierno, 23(2), 409-435.

Snopes. (2017). Did a 'Muslim Migrant' Beat Up a Dutch Boy on Crutches? Fact Check. (November 29) https://www.snopes.com/fact-check/video-beating-dutch-boy-crutches/. Accessed 29 June 2019.

Snopes. (2018-2019). Fact Check. The latest rumors, memes, and junk news debunked by Snopes. Snopes (June 19) https:/www.snopes.com/fact-check/does-law-family-separation-detention-minors/. Accessed 29 June 2019.

SOSRacismo Gipuzkoa. (2018). Observatorio de la diversidad. http://medios.mugak.eu/search/17698?sort= date\#facets month tag. Accessed 29 June 2019.

Spencer, H. S. (2018). Photo not related to 'caravan'. Factcheck (November 2) https://www.factcheck. org/2018/11/photo-not-related-to-caravan/. Accessed 29 June 2019.

Statista. (2019). Most popular Facebook activities in the United States as of October 2017. https://www. statista.com/statistics/275788/share-of-facebook-user-activities/. Accessed 29 June 2019.

Toret, J. (2012). Una mirada tecnopolitica sobre los primeros dias del 15M. Democracia Distribuida. Miradas de la Universidad Nómada al, 15M. Accessed 29 June 2019.

Toret, J. (2013). Tecnopolítica: la potencia de las multitudes conectadas. El sistema red 15M, un nuevo paradigma de la política distribuida. IN3 Working Paper Series. Accessed 29 June 2019.

UNHCR (2018) La cifra de muertos en el Mediterráneo en 2018 supera los 2.000. Notas de prensa. https://www.acnur.org/noticias/briefing/2018/11/5be185404/la-cifra-de-muertos-en-el-mediterraneo-en2018-supera-los-2000.html. Accessed 29 June 2019.

USAFACTS (2019). State of the union: The words, the facts, the data. USAFacts (February 5). https://usafacts. org/reports/state-of-the-union. Accessed 29 June 2019.

Van Aelst, P., Strömbäck, J., Aalberg, T., Esser, F., de Vreese, C., Matthes, J., Hopmann, D., Salgado, S., Hubé, N., Stępińska, A.,Papathanassopoulos, S., Berganza, R., Legnante, G., Reinemann, C., Sheafer, T., Stanyer, J., (2017) Political communication in a high-choice media environment: a challenge for democracy?. Annals of the International Communication Association 41 (1):3-27

Viejo, M. (2018). La estrategia de Vox en redes sociales: ya es el primer partido en Instagram, la plataforma con más jóvenes. El País. (December 16) https://elpais.com/politica/2018/12/12 /actualidad/1544624671_005462.html. Accessed 29 June 2019.

Vosoughi, S., Roy, D., \& Aral, S. (2018). The spread of true and false news online. Science, 359(6380), 11461151.

VOX (2019). 100 medidas urgentes de VOX para España. Programa Electoral. https://www.voxespana.es/. Accessed 29 June 2019.

Washington Post (2018-2019). Fact Checks 2018-2019. Retrieved from https://www.washingtonpost. com/news/fact-checker/?utm term=.bb3bca86c4f0. Accessed 29 June 2019.

Westheimer, J. (2018). Democratic goals for education in the digital age. Teaching Citizenship in the Digital Area. Education Canada (December), 23-27. www.edcan.ca/magazine EdCan.. Accessed 29 June 2019. 


\section{Affiliations}

Paul R. Carr ${ }^{1}$ - Sandra Liliana Cuervo Sanchez ${ }^{2}$ - Michelli Aparecida Daros ${ }^{3}$

1 Département des sciences d l'éducation, Université du Québec en Outaouais, 283, boulevard AlexandreTaché, C.P. 1250, succursale Hull, Gatineau, Québec J8X 3X7, Canada

2 Universidad del País Vasco, Leioa, Spain

3 Pontifícia Universidade Católica de São Paulo, São Paulo, Brazil 